\title{
Protein Level and Protein Energy Ratio that Produce the Best Gonad Quality of Sea Urchin Tripneustes Gratilla
}

\author{
Agnette T \\ Department of Fisheriesand Marine Resources \\ University of NusaCendana, Kupang
}

M. Zairin

Department of Aquaculture, Bogor Agricultural University, Bogor

\section{Mokoginta}

Department of Water Resource Management, Bogor Agricultural University, Bogor

\author{
M. A. Suprayudi
}

Department of Water Resource Management, Bogor Agricultural University, Bogor

\author{
F. Yulianda
}

Department of Water Resource Management, Bogor Agricultural University, Bogor

Received: December 20, 2013 Accepted: January 3, 2014

doi:10.5296/jbls.v5i1.5076 URL: http://dx.doi.org/10.5296/jbls.v5i1.5076

\begin{abstract}
The study aims to determine protein leveland protein energy ratio that producethe best gonad qualityof sea urchin Tripneuestes gratilla. Sea urchin were fed nine test diets with the combination ratio of protein level $(\%)$ and protein energy $(\mathrm{kcalGE} / \mathrm{g})$ namely; A (22:9), B (22:11), C (22:13), D (27:9), E (27:11), F (27:13), G (32:9), H (32:11), and I (32:13).
\end{abstract}


Treatment $\mathrm{G}$ produced the best gonad quality with gonad weight, gonad protein and gonad colour of $3.49 \mathrm{~g}, 64.45 \%$ and pale yellow until orange, respectively. Treatmen $\mathrm{G}$ also showed carotenoid total ranged from 15 to $18 \mathrm{ppm}$ and $\beta$-carotene ranged from 5 to $6 \mathrm{ppm}$. Moreover, this treatment exhibited gonad weight and gonad protein resulting in significantly difference $(\mathrm{P}<0.05)$ protein level, protein energy ratio and its interaction. However, carotenoid total and $\beta$-carotenedid not exhibit any diffrence $(p>0.05)$.

Keywords: Tripneustes gratill, Protein, Energy, Gonad quality, Carotenoid

\section{Introduction}

The increasing of gonad price from US $\$ 6$ to $\$ 400 \mathrm{~kg}^{-1}$ (Robinson et al. 2002; Sphigel et al. 2005; Pearce et al. 2002), the stable market askingandover fishingin several countries (Hammer et al. 2006; Siikavuopio et al. 2004, 2006)have supported the development of sea urchin cultivation. The developmentof sea urchin culture has been purposed to increase production and gonad quality. Production and gonad quality of sea urchin are influenced by the gonad growth level and nutrition quality.

Commonly, species of sea urchin use macroalgae as their food. Nevertheless, macroalgae use as food source has been less optimal due to 1) the limitation of macroalgae species source in nature, 2) variety of algae quality and 3) the difficulty of mass algae storage. Therefore, the development of artificial feed has been carried out to culture several species of sea urchin such as Pseudocentrotus depressus(Unuma et al., 1999; Akiyama et al., 2001); Lytechinus variegatus(Wasson et al., 1998; Hammer et al., 2004, 2006 );Strongylocentrotus droebachiensis(Wasson et al., 1998; Hammer et al., 2004, 2006 );andParacentrotus lividus(Wasson et al., 1998; Hammer et al., 2004, 2006 ) but, nutrition need and physical condition of sea urchin differ among species.

The nutrient availability in artificial feed will influence the development and production of sea urchin gonad. Protein content in feed gives the effect on gonad protein content resulting in the increasing of nutritive phagocite size. The feed energy content is one important factor during gonad development and maturation in reproduction cyclus beside protein (Schlosser et al., 2005). Feed with low energy content will cause sea urchin to use a part of protein as energy source for methabolism. It causes the lack of protein need for gonad development and maturation. In turn, feed with high energy content will result in the limitation of protein number eaten. However, the information of feed energy influence particularly protein energy ratio in feed on sea urchin gonad production has still been limited. Since protein has been one richcomponent in feed of sea urchin culture, it is required to determine the optimal protein level need and protein energy ratio for the maximum growth and gonad production in more eficience protein use.

Tripneustes gratillais one of dominant sea urchin species which has a potential for being developedin Indonesia particularly in Kupang bay. Nevertheless, study on gonad quality improvement and nutrition need information of sea urchin (T. gratilla) culture have still been limited. Therefore, this study aims to determine protein level and protein energy ratio that produce the best gonad quality of $T$. gratilla. 


\section{Material and Method}

\subsection{Time and Research Place}

Study was carried out from April to September 2009. Sea urchin (T. Gratilla) rearing in Department of Fisheries and Marine Laboratory of UNDANA. Preparing of feed materials, feed proximate test and gonad were done in Nutrition and Fish Health Laboratory, Institute of Bogor Aqriculture (IPB). Whilst, carotenoid total and $\beta$-carotene of gonad were conducted on postharvest laboratory of Agency for Bogor Aqricultural Postharvest Research and Development.

\subsection{Test Feed}

Materials used for feed formulation were fish flour, soya flour, corn flour, white flour, sargassum flour, fish oil, sargassum extract, agarose, vitamine mixture, mineral mixture, and etoxyquin with ingredients and the result of proximate analysis are listed in table 1 and Table 2.

\subsection{Rearing and Data Collection}

Adult sea urchin with the body diameter of 50-60 mm were collected from the wild and held in laboratory aquarium. Those sea urchin were acclimatized for two weeks. During the acclimatization process, sea urchin were fed commercial feed at $3 \%$ of body weight once a day. The healthy sea urchin were selected and cultured in aquariums with the sizing of $50 \times 50 \times 30$ $\mathrm{cm}$ each containing $10 \mathrm{~L}$ filtered seawater at $30 \mathrm{ppt}$. The density of sea urchin was 20 ind/rearing unit. All rearing units were provided with gentle and continuous aeration. All the rearing units were also completed with termometer. Sea urchin were then fasted for two weeks thereafter, they were fed with test feed at $3 \%$ of body weight every two days satiately. Feed residue in the rearing units were removed by siphoning.This studyused Completely Randomized Design with 2 factors consisted of 9 treatments and 3 repetitions. The first factor was protein level in which protein level percentage used were 22, 27 and 32\%. The second factor was protein energy ratio (C/P) with protein energy level of 9, 11 and 13 (kkalGE/g). The treatment combination ratio between protein level and protein energy was A (22:9), B (22:11), C (22:13), D (27:9), E (27:11), F (27:13), G (32:9), H (32:11), and I (32:13).In the end of study, gonad weight, protein level, carotenoid total, $\beta$-caroten, and gonad colourof sea urchin was measured.Gonad protein level was determined by using Kjeldahl method as described by Tekeuchi (1988). Meanwhile, carotenoid total and $\beta$-caroten of gonad were measured by using spectrophotometer and HPLCas described by Apriyantono et al. (1989);Agatsuma et al. (2005) and Barclayet al. (2006)withsomemodifications

Table 1. Formulation percentage of test feed materials (\%) with the similar content of vitamin mix, mineral mix, vitamin $\mathrm{C}$, agarose, etoxyquin/BHT, and sargassum extract

\begin{tabular}{|l|c|c|c|c|c|c|c|c|c|}
\hline \multirow{3}{*}{ Material (\%) } & \multicolumn{10}{|c|}{ Treatment } \\
\cline { 2 - 11 } & A & B & C & D & E & F & G & H & I \\
\hline Corn flour & 3.00 & 9.00 & 15.00 & 3.00 & 7.00 & 10.00 & 7.00 & 12.00 & 8.00 \\
\hline Fish flour & 24.00 & 22.00 & 22.00 & 31.00 & 28.00 & 27.50 & 35.00 & 35.00 & 35.00 \\
\hline
\end{tabular}




\begin{tabular}{|l|l|l|l|l|l|l|l|l|l|}
\hline Sargassum flour & 5.00 & 8.00 & 10.00 & 6.00 & 10.00 & 15.00 & 7.00 & 10.00 & 15.00 \\
\hline Soya flour & 15.00 & 15.00 & 13.00 & 17.00 & 17.00 & 16.00 & 21.00 & 19.00 & 19.00 \\
\hline White flour & 5.00 & 5.00 & 5.00 & 3.00 & 7.45 & 7.45 & 3.00 & 5.00 & 1.00 \\
\hline Fish oil & 0.50 & 1.00 & 3.00 & 1.00 & 2.50 & 6.00 & 1.00 & 4.00 & 12.00 \\
\hline Vitamine Mix & 2.00 & 2.00 & 2.00 & 2.00 & 2.00 & 2.00 & 2.00 & 2.00 & 2.00 \\
\hline Mineral Mix & 2.00 & 2.00 & 2.00 & 2.00 & 2.00 & 2.00 & 2.00 & 2.00 & 2.00 \\
\hline vit amine C & 0.08 & 0.08 & 0.08 & 0.08 & 0.08 & 0.08 & 0.08 & 0.08 & 0.08 \\
\hline Agarose & 5.00 & 5.00 & 5.00 & 5.00 & 5.00 & 5.00 & 5.00 & 5.00 & 5.00 \\
\hline Etoxyquin/BHT & 0.02 & 0.02 & 0.02 & 0.02 & 0.02 & 0.02 & 0.02 & 0.02 & 0.02 \\
\hline Sargassum extract & 0.03 & 0.03 & 0.03 & 0.03 & 0.03 & 0.03 & 0.03 & 0.03 & 0.03 \\
\hline Cellulose & 38.37 & $30 ., 87$ & 22.87 & 29.87 & 18.92 & 8.92 & 16.87 & 5.87 & 0.87 \\
\hline
\end{tabular}

Table2. Proximate composition percentage (\% of dry weight) of test feed in the third study

\begin{tabular}{|c|r|r|r|r|r|}
\hline \multirow{2}{*}{ Treatment } & \multicolumn{5}{|c|}{ Proximate composition (\%) } \\
\cline { 2 - 6 } & Ash content & Protein & Fat & \multicolumn{2}{|c|}{ Carbohydrate } \\
\cline { 4 - 6 } & & & & Coarse fibre & BETN \\
\hline A & 16.21 & 22.21 & 3.95 & 25.46 & 32.17 \\
B & 16.02 & 22.77 & 5.57 & 21.76 & 33.88 \\
C & 15.44 & 22.12 & 9.85 & 16.39 & 36.20 \\
D & 17.31 & 26.73 & 6.22 & 18.97 & 30.77 \\
E & 16.42 & 26.69 & 8.93 & 15.71 & 32.25 \\
F & 15.71 & 26.34 & 16.02 & 9.29 & 32.64 \\
G & 16.53 & 31.82 & 5.95 & 19.72 & 25.98 \\
H & 16.96 & 31.70 & 12.13 & 8.96 & 30.25 \\
I & 16.91 & 31.67 & 27.25 & 3.69 & 20.48 \\
& & & & & \\
\hline
\end{tabular}

Note: Combination treatment between protein level (\%) and protein energy (kcalGE/g) of A (22:9); B (22:11); C (22:13); D (27:9); E (27:11); F (27:13); G (32:9); H (32:11); and I (32:13)

Gonad colour was subjectively tested by three respondents. The colour of gonad was then compared to prepared card colour and continued to be arranged in gonad colour percentage by grouping each gonad in several categories as in category modified by[9]as followed:

$1=$ very good (light yellow or orange)

$2=\operatorname{good}($ pale yellow $)$

$3=$ mild (yellow-brown, orange - brown, brown red, cream)

4 = bad (dark brown, gray, green)

\subsection{Data Analysis}

Gonad weight, gonad protein, carotenoid total, and $\beta$-caroten data were analyzed by two-way analysis of variance(Steel dan Torrie, 1982)usingSPSS Version 13.0 software packages.Differences of results were considered statistically significant difference if the $P$ 


\section{Macrothink}

value were $\leq 0.05$. The color of gonad was descriptively analyzed by using Microsoft Excel 2007 programme.

\section{Result and Discussion}

\subsection{Result}

\subsubsection{Gonad Weight}

The highest gonad weight was shown by the treatment of G (32: 9) namely2.25 g. In contrast, the treatment of A (22:9)gave the lowest gonad weight $(0.38 \mathrm{~g})$ (Figure 1). Among the treatment of $\mathrm{A}, \mathrm{B}$ and $\mathrm{C}$ with protein level of $22 \%$ and $\mathrm{C} / \mathrm{P}$ ratio of 9,11 and $13 \mathrm{kcal} \mathrm{GE} / \mathrm{g}$, respectively, the treatment of $\mathrm{C}$ (22:13) showedthe highest gonad weight. Meanwhile,from the treatments of $\mathrm{G}, \mathrm{H}$, I with protein level of $32 \%$ and $\mathrm{C} / \mathrm{P}$ ratio of 9,11 and $13 \mathrm{kcal}$, the highest gonad weight was displayed by the treatment of $\mathrm{G}(32 ; 9)$. It indicated that the treatment with the low protein level was needed the high $\mathrm{C} / \mathrm{P}$ ratio. In turn, at the treatment with the high protein level was neededthe low $\mathrm{C} / \mathrm{P}$ ratio.In addition, it could be said that in the $\mathrm{G}$ treatment, the optimal feed protein was used to increase gonad weight of sea urchin.Furthermore, protein level andinteraction of protein level and protein energyratio gave the significant effect on the increase of sea urchin gonad weight. However, protein energyratio itself exhibited no any significant effect $(P>0.05)$ on gonad weight of sea urchin.

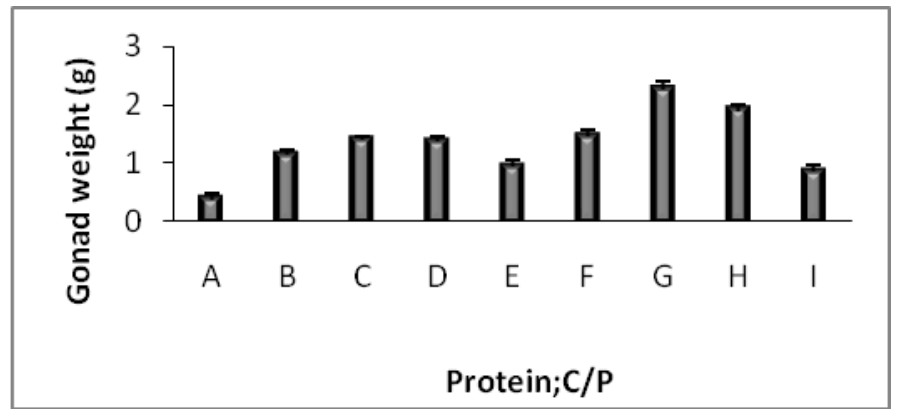

Figure 1. Sea urchin gonad weight (g) at different proteinlevel andprotein energy ratio(gonad weight average $\pm S D ; n=3$ ).

\subsubsection{Gonad Protein}

The average of gonad protein level in each treatment was range from 48.25 to $64.45 \%$ (Figure 2). Sea urchin $(T$. gratilla)given feed at the treatment $\mathrm{G}$ with protein level $(\mathrm{P})$ of $32 \%$ and $\mathrm{C} / \mathrm{P}$ ratio of 11 produced the highest gonad protein $(64.45 \%)$. It showed that feed protein increasing was able to increase gonad protein content of sea urchin. In this study, protein level and interaction between protein level andprotein energy ratio pakan showed a significantly different gonad protein level $(P<0.05)$ in contrast, protein energy ratio did not exhibit any different gonad protein content $(P>0.05)$. 


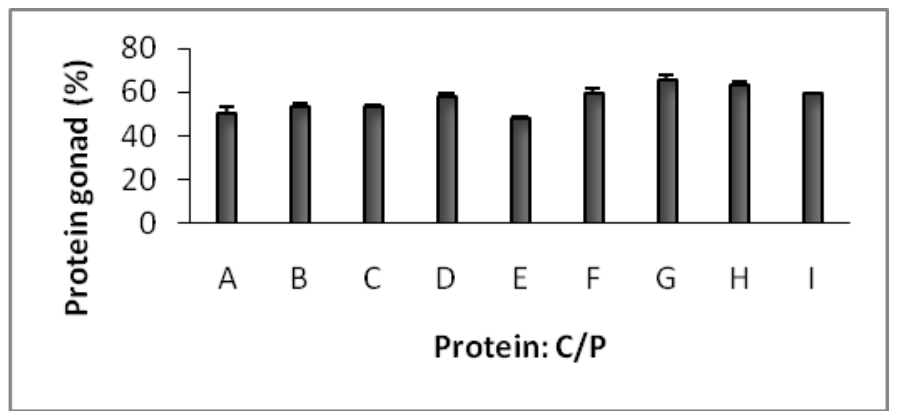

Figure 2. Sea urchin gonad protein at differenttreatment of protein level andprotein energy ratio (protein average $\pm \mathrm{SD} ; \mathrm{n}=3$ ).

\subsubsection{Carotenoid Total and $\beta$-carotene}

The highest gonad carotenoid total was found at the B $(18.18 \mathrm{ppm})$ and the lowest gonad carotenoid total was obtained at the treatment F (13.98 ppm). In general, gonad carotenoid total average tended to decrease with protein energy ratio increasing. The lowest gonad carotenoid total was shown by the treatment F (13 kcal GE/g) (Figure3). The carotenoid analysis displayed that protein level,feed protein energy ratioand interaction between protein level andprotein energy ratio gave no significant effect on gonad carotenoid total $(P>0.05)$.

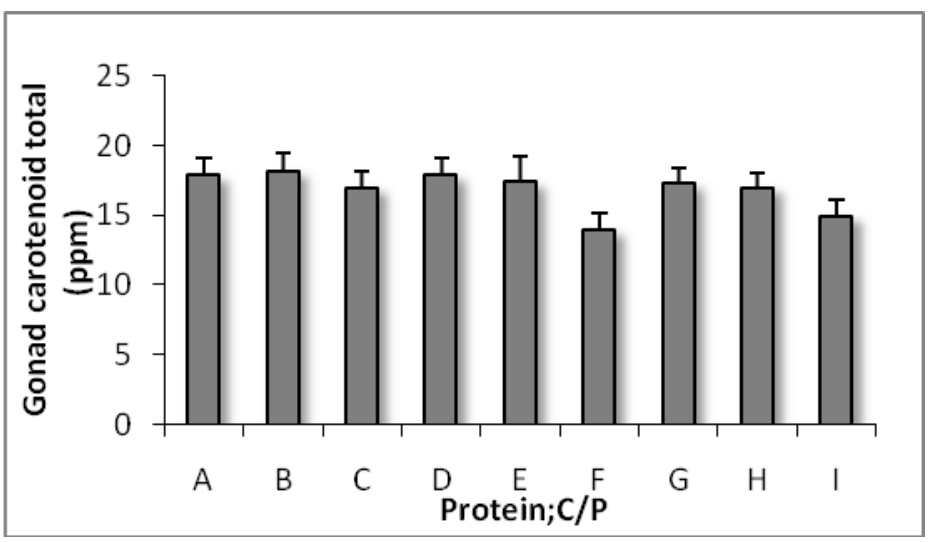

Figure 3. Gonad carotenoid total levelof sea urchin at different treatment of protein level andprotein energyratio (Carotenoid total average $\pm \mathrm{SD} ; \mathrm{n}=3$ ).

From this study, it could be obtained that gonad carotenoid acumulation was influenced byfeed protein energyratio. The increasing of feed protein energy ratio was suspected to cause the lack of carotenoid taking or absorption binding with protein to gonad due to the more feed fat content as the main energy source of feed.

The highest gonad $\beta$-carotenecontent was also shown by the treatment $\mathrm{B}(6.26 \mathrm{ppm})$ and the lowest gonad $\beta$-carotene content was obtained at the treatment F (4.78 ppm) (Figure4). The protein level, protein energy ratio and interaction between protein level andfeed protein energyratio did not give any significant effect on $\beta$-caroteneof gonad $(P>0.05)$. 


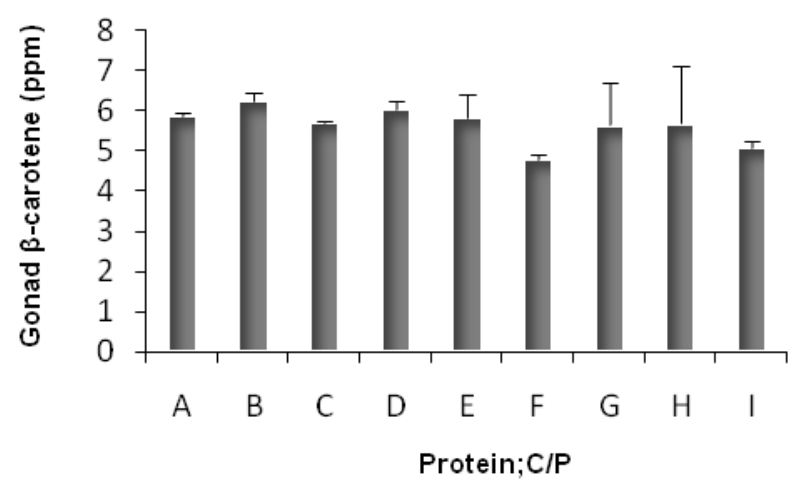

Figure 4. Gonad $\beta$-carotenelevel of sea urchin at different treatment of protein level andprotein energyratio (Carotenoid total average $\pm \mathrm{SD} ; \mathrm{n}=3$ ).

$\beta$-carotene content showed the similar pattern to carotenoid total content. Compared to gonad carotenoid total, gonad $\beta$-caroteneshowed a third of carotenoid total and the rest of carotenoid total were converted into the other forms which were suspected to be retinal, retinoland echinenon.

\subsubsection{Gonad Colour}

Gonad colour obtained was in the second group with gonad colour score average of 2-2.83 indicating a good gonad colour quality. The evaluation of gonad colour (Figure 5) exhibited the similar pattern to carotenoid total and gonad $\beta$-carotene.

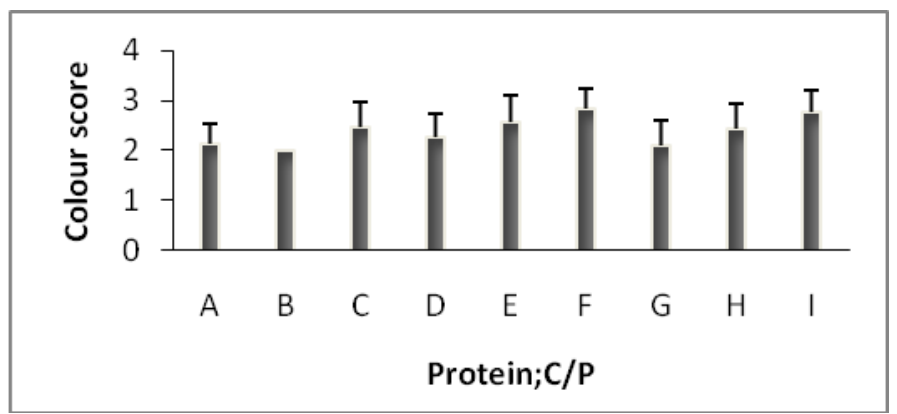

Figure5. Sea urchin gonad colour evaluation at different tretment of protein level andprotein energy ratio (Carotenoid total average $\pm S D ; n=3$ ).

Theobservation of rearing wáter quality parameters wassuitable fort hegrowth of sea urchin during the experiment. Temperature, salinity, $\mathrm{pH}$, and ammonia cobtained wereranged from 26 to $28{ }^{\circ} \mathrm{C}, 29$ to $32 \mathrm{ppt}, 7.2$ to 7.8 , and 0.019 to $0.188 \mathrm{mg} / \mathrm{l}$, respectively.

\subsection{Discussion}

The main component of vitelogenin is protein (lipoprotein). Feed protein content will influence gonad protein content indicated by the increasing of nutritive phagocite size which has a function as protein storage. Beside protein content, feed energy content and physiology factor of fish give the effect on gonad protein content. 
In this study, $32 \%$ protein level and $9 \mathrm{kcal} \mathrm{GE} / \mathrm{g}$ optimal protein energy ratio $(\mathrm{C} / \mathrm{P})$ were able to increase gonad weight and gonad protein content of sea urchin (Tripneustes gratilla). Investigation byAkiyama et al. (2001) on Paracentrotus depressur with $15 \mathrm{~mm}$ in diameter obtained that sea urchin fed with protein content 20,30 and 40\% had the higher gonad index $(P<0.05)$ than sea urchin fed with protein content 10 and 50\% $(P>0.05)$. Meanwhile, Pearce et al. (2004) found that adult Strongylocentrotus droebachiensiswith body diameter of $59.6 \pm 4.1$ $\mathrm{mm}$ fed with feed protein content of 19, 24 and $29 \%$ resulted in the similar gonad index and those treatments gave the significantly different gonad index compared to control feed (kelp) with feed protein content of $8.7 \%$. Moreover, Lytechinus variegatus with body diameter of 14 $\mathrm{mm}$ fed with feed protein content of $9,15,21$, and $33 \%$ for 14 weeks showed the maximun growth andsurvival rate of sea urchin given feed with protein content of $\geq 21 \%$ (Hammer et al. 2004).Based on those results, it can be explained that each sea urchin needs a different protein level to grow and produce gonad. The need of protein level is also influnced by the age and size of sea urchin. In general, sea urchin needs protein around 20-40\% in its feed(Schlosser et al. 2005).

This study also showed the presence of a positive relationship between gonad weight and gonad protein indicated by regression linear namely; gonad protein $=47.25+7.3$ of gonad weight with R2 $=54.7 \%$. It means the higher gonad weight the higher gonad protein level and in turn. Compared to the research done by Tjendanawangi et al. (2009), time need to reach maturation and spawn in this study was 2-4 weeks faster. It showed that the effective feed protein would fasten the growth and maturation sea urchin gonad. It was caused by vitelogenesis process in which there was occurred vitelogenin accumulation being the main component from protein to nutritive phagosite cell causing the increasing of gonad weight and the development and gonad maturation process being faster(Unuma, 1999) Beside protein, the faster growth and gonad were also suspected due to the function of carotenoid content in feed (0.155-0.464 ppm). According to Regunathan and Wesley (2006), carotenoid has the ability to increase shrimp vitelogenesis and directly gave the effect on hormon gene transcription which has an important function in ovary maturation. During vitelogenesis, carotenoidis moved from hepatopankreas too vary throught haemolym in which the carotenoid is accumulated in oosit as the mincomponent of egg yellow protein (lipovitelin) (Torinsen dan Torinsen 1985; Lubzends et al. 2003; Regunathan dan Wesley 2006).

The best quality of gonad colour is if gonad has a colour of light yellow or orange and red. Whilst, the good quality of that if it has a colour of pale yellow or orangeand the bad quality was shown by gonad with pale colour, cream or brown. Yellow and orange sea urchin gonad were caused by the pigmen of carotenoid such as $\beta$-caroteneand echinenon in which both pigments are the main pigments in sea urchin gonad. Carotenoid total and $\beta$-carotene of sea urchin gonad were ranged from 15 to 18 and 5 to 6 ppm, respectively.

The evaluation of gonad colour, carotenoid total and gonad $\beta$-carotene tented to decrease at the treatment of $\mathrm{C}, \mathrm{F}$ and I with feed protein energy ratio increasing of $13 \mathrm{kcal} \mathrm{GE} / \mathrm{g}$. It was indicated that the accumulation of gonad carotenoid is influenced by protein energy ratio of feed. The increasing of feed protein energy ratio was suspected to be the causative of carotenoid taking or absorption decreasing binding with protein to gonad. It was caused by the 
high carbohydrate or feed fat as the main source of feed. It was also due to a part of intestine absorbed carotenoid converted to be retinol. Retinol was transported in cyrculatory system and in the plasm it was bound with retinol-binding protein (RBP) synthesized in liver and entered to oosit. Retinol in retinal form was bound with vitelogenin (VTG) then transported to oosit via plasmduring vitelogenesis (Lubzens et al. 2003; Sammar et al. 2005).. In sea urchin gonad, a big part of carotene are also converted to echinenon through isocriptoxantin(Plank et al 2002; Robinson et al. 2002; Shpigel et al 2005).

\section{Conclussion}

Protein level andfeed protein energy ratio influnced on gonad quality of sea urchin T. gratilla. The giving of artificial feed with protein level of $32 \%$ and protein energy ratio of $9 \mathrm{kcalGE} / \mathrm{g}$ protein resulted in the best production and gonad quality.

\section{Acknowledgement}

The authors thanked DIKTI, Indonesia for funding research and Nutrition and Fish Health Laboratory staffs of FPIK, IPB. The authors also thanked to Balai Besar Penelitian and Pengembangan Pascapanen Pertanian Bogor staffs.

\section{Refferences}

Agatsuma Y, Sato M, \& Taniguchi K. (2005). Factor Causing Brown-Colored Gonads of The Sea Urchine, Strongylocentrotusnudus, in Northern Honshu, Japan. Aquaculture, 249, 449-458. http://dx.doi.org/10.1016/j.aquaculture.2005.04.054

Akiyama T, Unuma T, \& Yamamoto T. (2001). Optimum Level in A Purified Diet for Young Red Sea Urchin Pseudocentrotus depressus. Fisheries Science, 67, 361-363. http://dx.doi.org/10.1046/j.1444-2906.2001.00252.x

Barcay M. C, Irvin S. J, Williams K. C, \& Smith D. M. (2006). Comparison of Diets for The Tropical Spiny Lobster Panulirusornatus; Astaxantin-Supplemented Feeds and Mussel Flesh. Aquaculture Nutrition, 12, 117-125. http://dx.doi.org/10.1111/j.1365-2095.2006.00390.x

Daggett T. T, Pearce C. M, Tingley M, Robinson S. M. C, \& Chopin T. (2005). Effect of Prepared and Macroalgal Diets and Seed Stock Source on Somatic Growth of Juvenile Green Sea Urchins (Strongylocentrotus droebachiensis). Aquaculture, 244, 263-281. http://dx.doi.org/10.1016/j.aquaculture.2004.11.030

Fernandez C, \& Boudouresque C. (2000). Nutrition of The Sea Urchin Paracentrotuslividus (Echinodermata: Echinodea) Fed Different artificial food. Marine Ecology Progress Series, 204, 131-141. http://dx.doi.org/10.3354/meps204131

Fernandez C, \& Pergent G. (1998). Effect of DifferentFormulatedDiets and Rearing Conditionson Growth Parameters in The Sea Urchin Paracentrotuslividus. Journal of Shellfish Research, 17(5), 1571-1581.

Hammer H, Watts S, Lawrence A, Lawrence J, \& Desmond R. (2006). The Effect of Dietary Protein on Consumption, Survival, Growth and Production of The Sea Urchin 
Lytechinusvariegatus.

Aquaculture,

254

483-495.

http://dx.doi.org/10.1016/j.aquaculture.2005.10.047

Hammer R. W, Hammer H. S, Watts S. A, Desmond R. A, Lawrence J. M, \& Lawrence A. L. (2004). The Effect of Dietary Protein Concentration on Feeding and Growth of Small Lytechinusvariegatus (Echinodermata: Ecnhinoidea).. Marine Biology, 145, 1143-1157. http://dx.doi.org/10.1007/s00227-004-1391-x

Lubzens E, Lissauer L, Levavi-Sivan B, Avarre J. C, \& Sammar M. (2003). Carotenoid and Retinoid Transport to Fish Oocytes and Eggs: What is The Role of Retinol Binding Protein?. Molecular Aspects of Medicine, 441-457. http://dx.doi.org/10.1016/S0098-2997(03)00040-2

Pearce C. M, Daggett T. L, \& Robinson S. M. C. (2002). Effect of Protein Source Ratio and Protein Concentration in Prepared Diets on Gonad Yield and Quality of The Green Sea Urchin, $\begin{array}{lll}\text { Strongylocentrotus } \quad \text { droebachiensis. } & \text { Aquaculture, } & 214,\end{array}$ http://dx.doi.org/10.1016/S0044-8486(02)00041-8

Pearce C. M, Daggett T. L, \& Robinson S. M. C. (2004). Effect of Urchin Size and Diet on Gonad Yield and Quality in The Green Sea Urchin, Strongylocentrotus droebachiensis. Aquaculture, 233, 337-367. http://dx.doi.org/10.1016/j.aquaculture.2003.09.027

Plank L. R, \& Lawrence J. M. (2002). The Effect of Dietary Carotenoids on Gonad Production and Carotenoid Profile in The Sea Urchin Lythecinusvariegatus. Journal of The World Aqaculture Society, 33(2), 127-137. http://dx.doi.org/10.1111/j.1749-7345.2002.tb00487.x

Regunathan C, \& Wesley S. G. (2006). Pigment Defisiensi Correction in Shrimp Broadstock Using Spirulin as A Carotenoid Source. Aquaculture Nutrition, 12, 425-432. http://dx.doi.org/10.1111/j.1365-2095.2006.00444.x

Robinson S. M. C, Castell J. D, \& Kennedy E. J. (2002). Devoloping Suitable Colour in The Gonads of Cultured Green Sea Urchine, Strongylocentrotus droebachiensis. Aquaculture, 206, 289-303. http://dx.doi.org/10.1016/S0044-8486(01)00723-2

Sammar M, Levi L, Hurvitz A, \& Lubzens E. (2005). Studies on Retinol-Binding Protein During Vitelogenesis in The Rainbow Trout (Oncorhynchusmykiss). General and Comperative Endocrinology, 141, 141-151. http://dx.doi.org/10.1016/j.ygcen.2004.12.014

Schlosser S. C, Lupatsch I, Lawrence J. M, Lawrence A. L, \& Sphigel M. (2005). Protein and Energy Digestibility and Gonad Development of The European Sea Urchin Paracetrotuslividus (Lamarck). Fed Algal and Prepared Diets during Spring and Fall. Aquaculture Research, 36, 972-982. http://dx.doi.org/10.1111/j.1365-2109.2005.01306.x

Shpigel M, McBride S. C, Marciano S, Ron S, \& Ben-Amotz A. (2005). Improving Gonad Colour and Somatic Index in European Sea Urchine Paracentrotuslividus. Aquaculture, 245, 101-109. http://dx.doi.org/10.1016/j.aquaculture.2004.11.043

Siikavuopio S. I, Christiansen J. S, \& Dale T. (2006). Effects of Temperature and Season on Gonad Growth and Feed Intake in The Green Sea Urchin Strongylocentrotus droebachiensis. 


\section{Macrothink}

Aquaculture, 255, 389-394. http://dx.doi.org/10.1016/j.aquaculture.2005.12.021

Siikavuopio S. I, Dale T, Foss A, \& Mortensen A. (2004). Effect of Chronic Ammonia Exposure on Gonad Growth and Survival in Green Sea Urchin Strongylocentrotus droebachiensis.

Aquaculture, 242 ,

313-320.

http://dx.doi.org/10.1016/j.aquaculture.2004.08.042

Steel R. G. D, \& Torrie J. H. (1982). Principle and Procedures of Statistics, A Biometrical Approach. Second edition. Florida: CRC Press.

Tjendanawangi A, Zairin J, Ing M, Fredinan Y, \& Agus S. (2009). Profil Hormon Steroid selama Perkembangan Gonad Bulubabi Tripneueste gratilla dalam Wadah Budidaya. Aquacultura Indonesiana, 10(3), 149-155.

Torinsen KR, \& Torinsen OJ. (1985). Protease Activities and Carotenoid Levels during The Sexual Maturation of Atlantic Salmon, Salmosalar. Aquaculture, 50, 113-122. http://dx.doi.org/10.1016/0044-8486(85)90157-7

Unuma T, Yamamoto T, \& Akiyama T. (1999). Effect of Steroid on Gonadal Growth and Gametogenesis in The Juvenile Red Sea Urchin Pseudocentrotus depressus. Biol. Bull. 196, 199-204. http://dx.doi.org/10.2307/1542565

Wasson K. M, Hines G. A., \& Watts S. A. (1998). Synthesis of Testosteron and $5 \alpha$-Androstanediols during Nutritionally Stimulated Gonadal Growth in Lytechinusvariegatus Lamarck (Echinodermata: Echinodea). General and Comperative Endocrinology, 111, 197-206. http://dx.doi.org/10.1006/gcen.1998.7105

\section{Copyright Disclaimer}

Copyright reserved by the author(s).

This article is an open-access article distributed under the terms and conditions of the Creative Commons Attribution license (http://creativecommons.org/licenses/by/3.0/). 